\title{
Relationship between perceived organizational politics, organizational trust, human resource management practices and turnover intention among Nigerian nurses
}

\author{
Ramatu Abdulkareem Abubakar ${ }^{a^{*}}$, Ajay Chauhan ${ }^{a}$ and Kabiru Maitama Kura ${ }^{a, b}$
}

${ }^{a}$ Othman Yeop Abdullah Graduate School of Business, Universiti Utara Malaysia, Sintok, Malaysia

${ }^{b}$ Department of Business Administration and Management, Federal Polytechnic Kaura-Namoda, Zamfara State, Nigeria

CHRON I C L E

Article history:

Received January 20, 2014

Accepted 5 July 2014

Available online

August 142014

Turnover intentions

Organizational politics

Organizational trust

Human resource practices

Nigerian hospitals \begin{abstract}
A B S T R A C T
Prior research has indicated that employee turnover is detrimental to both individuals and organisations. Because a turnover intention in the workplace is detrimental, several factors have been suggested to better understand the reasons why employees may decide to leave their organisations. Some of the organizational-related factors that have been considered by previous research include perceived organizational justice, job satisfaction, perceived psychological contract breach, and perceived organizational support, among others. Despite these empirical studies, literatures indicate that less attention has been paid to the influence of perceived organisational politics, organizational trust, and perceived human resource practices management (HRM) practices on employee turnover. Hence, the present study fills in the gap by examining the relationship between perceived organisational politics, organizational trust, perceived human resource management practices and employee turnover among Registered Nurses in Nigerian public hospitals using multiple regression analysis technique. One hundred and seventy five Registered Nurses participated in the study. Result indicated that perceived organisational politics was significantly and positively related to turnover intentions. The result also showed that both organizational trust and perceived human resource practices were significantly and negatively related to turnover intentions. Theoretical and practical implications of the results are discussed.
\end{abstract}

\section{Introduction}

In his Seminal work, Price (1977) defined employee turnover as the as the ratio of the number of organizational members who had left, either voluntarily or involuntarily during the period under consideration, to the total number of people in that organization during the period. The focus of this study is turnover intention rather than actual turnover, because behavioural intention is the immediate antecedent of the actual behaviour (Ajzen, \& Fishbein, 1980; Fishbein, \& Ajzen, 1975). Employee turnover is prevalence and has become a major concern of every organization. For example, In the United States of America (U.S.A.), about $7.7 \%$ of the full time faculty members from various universities and colleges had left their posts for other institutions in 1997/1998 academic session. Of these faculty members, only $29 \%$ were retirees, while the remaining $71 \%$ have left their institutions *Corresponding author. 
for variety of reasons (Sanderson et al., 2000). The survey further showed that more than $40 \%$ of the faculty members in the USA have made of their minds to change careers (Sanderson et al., 2000).

In a similar survey, Waswa and Katana (2008) reported that in Kenya, qualified faculty members from various Kenyan public universities have quitted their job for a secured and better paying jobs abroad. Munzali and Obaje (2008) also reported that about $64 \%$ of the required number of teaching staff from various universities in Nigeria have left for western industrialized countries, such as USA, United Kingdom (UK), Southern Africa and Middle East countries, including Kuwait, Saudi Arabia and Oman, among others. Records have also shown that about 500 employees from various organisations in Nigeria continue to leave annually, to western economies such as United States, Europe, Canada and other African countries for better condition of service (Bassi, 2004). A recent estimates have shown that that in the year 2012, more than 20,000 professionals, including medical personnel, teaching staff from various universities and colleges leave African continent annually to look for a greener pastures in Western countries such as United States, Canada, Germany and United kingdom, among others (Agency Reporter, 2012).

Meanwhile, several studies have indicated that employee turnover is detrimental to both individuals and organisations (Glebbeek, \& Bax, 2004; Hellman, 1997). For instance, co-worker turnover, may be a "shock" to the remaining employees, which results in work disruption and also significantly reduce their job embeddedness, thereby triggering thoughts of quitting in them (Holtom et al., 2008). It is also estimated that employee turnover has a financial costs to organisations due to the separation costs; replacement costs of departed employees and training costs of new employees (Cascio, 2000; McKinney et al., 2007). Because of its prevalence and detrimental effects to both individuals and organisations, further studies are needed to better understand the reasons why employees may decide to leave their organisations.

Over the past 60 years, several factors have been suggested by industrial and organizational psychologists to better understand the reasons why employees may decide to leave their organisations, despite the monetary compensation they received from the organization (Adebayo, \& Ogunsina, 2011; Beecroft et al., 2008; Cotton, \& Tuttle, 1986; Grissom et al., 2012; March, \& Simon, 1958; Mobley, 1977, 1982; Mobley et al., 1979; Poon, 2004; Porter, \& Steers, 1973; Price, 1977). One of the significant predictors of employee turnover is related to the organization, because organizational factors are an important consideration in understanding employee attitude and behaviour at work because they are able to shape the way employees think, feel, and behave (Robbins and Judge, 2010). To date, some of the organizational-related factors that have been considered include perceived organizational justice (Ali, \& Jan, 2012; Cantor et al., 2011; Koys, 2001; Parker, \& Kohlmeyer III, 2005), organizational culture (Deery, \& Shaw, 1999; Gregory et al., 2009; San -Park, \& Kim, 2009; Way et al., 2007), job satisfaction (Grissom et al., 2012; Hellman, 1997; Koys, 2001; Mobley, 1977; San-Park, \& Kim, 2009; Yau-De et al., 2012), human resource management practices (Allen et al., 2003; Batt, \& Valcour, 2003; Haines III, Jalette, \& Larose, 2009; Kim, 2012; Long et al., 2012; Staufenbiel, \& König, 2010), perceived psychological contract breach (Blomme et al., 2010; Kickul, \& Lester, 2001) and perceived organizational support, among others (DeConinck, \& Johnson, 2009; Jawahar, \& Hemmasi, 2006; Maertz et al., 2007). In general, these studies found that unfavourable work environment as reflected by lack of organisational support, perceived psychological contract breach, poor human resource management practices and injustice at the workplace for example, are likely to have a significant influence on employee turnover.

Despite the aforementioned empirical studies on the role of organizational factors in predicting employee turnover at work, literatures indicate that less attention has been paid to the influence of perceived organisational politics, organizational trust, perceived human resource practices (HR practices) and employee turnover. Hence, there is a need to investigate the relationship between 
perceived organisational politics, organizational trust, perceived HRM practices and employee turnover. The purpose of this study was to to examine the relationship between organizational politics, organizational trust, human resource management practices and turnover intention among Nigerian nurses.

\section{Literature review}

\subsection{Turnover Intention}

Turnover intention is one of the most important attitudinal challenges that managers constantly faced at work. It has been defined as the tendency of employees to leave their jobs or organization that they are currently working for (Lee et al., 2012; Mobley, 1982; Price, 1977; Schyns et al., 2007). In a meta-analytic study of turnover intention, it is suggested that employee's intention to leave is the best predictor of the actual turnover behavior (Tett, \& Meyer, 1993). Similarly, Moore (2000) concurred that employee's intention to quit is a stronger signal of the actual turnover. Employee's turnover is costly to organisations. For example, it is estimated that employee turnover is costly to organisations regarding the separation costs; replacement costs of departed employees and training costs of new employees (Cascio, 2000; McKinney et al., 2007; Mobley, 1982).

Because of its significant costs, several factors have been suggested to explain why employees intent to leave. To date, some of the factors that have been considered include perceived organizational justice (Ali, \& Jan, 2012; Cantor et al., 2011; Koys, 2001; Parker, \& Kohlmeyer III, 2005), organizational culture (Deery, \& Shaw, 1999; Gregory et al., 2009; San-Park, \& Kim, 2009; Way et al., 2007), job satisfaction (Grissom et al., 2012; Hellman, 1997; Koys, 2001; Mobley, 1977; SanPark, \& Kim, 2009; Yau-De et al., 2012), human resource management practices (Allen et al., 2003; Batt, \& Valcour, 2003; Haines III et al., 2009; Kim, 2012; Long et al., 2012; Staufenbiel, \& König, 2010), perceived psychological contract breach (Blomme et al., 2010; Kickul, \& Lester, 2001) and perceived organizational support, among others (DeConinck, \& Johnson, 2009; Jawahar, \& Hemmasi, 2006; Maertz et al., 2007). Despite the aforementioned empirical studies, however, little studies have been conducted on the influence of perceived organisational politics, organizational trust and perceived HR practices on employee's turnover intention. Hence, these factors are chosen to be studied in the present research.

\subsection{Perceived Organisational Politics}

Perceived organisational politics is an important factor in explaining the reason why employees contemplate leaving their organizations in which they are currently working for. According to Ferris, Harrell-Cook and Dulebohn (2000), perceived organisational politics "involves an individual's attribution of behaviours of self-serving intent and is defined as an individual's subjective evaluation about the extent to which the work environment is characterized by co-workers and supervisors who demonstrate such self-serving behavior" (p. 90). While the management of an organisation cannot totally prevent the highly skilled employees from leaving their jobs or organisations, however it is important for managers to understand effects of organisational politics on employee's turnover intention, so as to minimize the occurrence of such decision.

In synthesizing the literature on the effects of perceived organisational politics on employee's turnover intention, it is valuable to discuss Blau's (1964) social exchange theory. Essentially, social exchange theory suggests that when organisational politics do not favour an employee, in return to that unfavourable work environment he/she is likely to consider leaving his/her job (Gouldner, 1960). Past research has demonstrated that organisational politics perceptions are important for predicting employees' turnover intention in a variety of contexts, including manufacturing, health sector, government, and banking sector, among others. Specifically, Vigoda (2000) conducted a study 
examine the relationship between perception of organizational politics, job attitudes, and work outcomes among 303 public sector employees in Israel. The study established a significant and positive relationship between perception of organizational politics and intentions of exit. Huang, Chuang and Lin (2003) examined the mediating effects of burnout on the relationship between perceived organizational politics and turnover intentions among 612 tax employees of the Ministry of Finance in Taiwan. The results showed that perception of organizational politics was positively and significantly related with turnover intentions. In addition, the study established that relationship between perceived organizational politics and turnover intentions was partially mediated by burnout, which is typically characterized by emotional exhaustion, cynicism and professional efficacy.

Harris et al. (2007) validated social exchange theory by conducting a study to investigate the moderating effects of distributive and procedural justice on the relationship between organizational politics and workplace attitudes (i.e., turnover intentions and job satisfaction) among 311 employees of a water management district in the south-eastern United States. As predicted, the results indicated that perceived organizational politics was positively related to turnover intentions and negatively related to job satisfaction. In addition, the results showed that the perceived organizational politics turnover intentions and perceived organizational politics-job satisfaction relationships were weaker when both perceived distributive and procedural justice are high. A meta-analytic study of 79 independent samples from 59 published and unpublished empirical studies among 25,059 individual participants, Miller, Rutherford and Kolodinsky (2008) found that perceived organizational politics was positively and significantly related with turnover intentions. Abbas et al., (2012) conducted a study to investigate the combined effects of perception of organizational politics and psychological capital on job satisfaction, turnover intentions, and performance among 237 white-collar employees across a variety of organizations, including textile-manufacturing firms, government ministry, and telecommunication firms in Faisalabad, Pakistan. The results provide a strong support for the proposed hypotheses that perception of organizational politics has a positive effect on turnover intentions and negative influence on job satisfaction and job performance

Recently, Bedi and Schat (2013) also conducted a meta-analytic study on the relationships between perceived organizational politics, attitudinal and behavioural outcomes on 118 independent samples, involving 44,560 individual participants. The results provide strong evidence that perceived organizational politics was positively and significantly related with turnover intentions. Chinomona and Chinomona (2013) also conducted a study to examine the effects of perceived organizational politics on turnover intentions among 300 non-managerial employees in Zimbabwe's Small and Medium Enterprises (SME) sector. They found perceptions of organizational politics to be significant predictor of turnover intentions.

\subsection{Organisational Trust}

Organisational trust has been defined by Cook and Wall (1980) "the extent to which one is willing to ascribe good intentions to and have confidence in the words and actions of other people" (p. 39). Similarly, according to Carnevale and Wechsler (1992) Organisational trust "involves faith or confidence in the intentions or actions of a person or a group, the expectation of ethical, fair, and nonthreatening behaviour, and concerns for the rights of others in exchange relationships" (p. 473). Meanwhile, organisational trust refers to "the willingness of a party to be vulnerable to the actions of another party based on the expectation that the other will perform a particular action important to the trustor, irrespective of the ability to monitor or control that other party" (Mayer et al., 1995, p. 712). Two dimensions of organisational trust have been identified in the literature, namely: trust in supervisor and trust in organization (Nyhan, \& Marlowe, 1997). Following Mayer et al. (1995) trust in supervisor, also known as interpersonal trust has been defined by Tan, and Tan (2000) as "the willingness of a subordinate to be vulnerable to the actions of his or her supervisors whose behaviour and actions he or she cannot control" (.p 243). On the other hand, trust in organization refers to the 
"employee's confidence that the organisation will perform an action that is beneficial or at least not detrimental to him or her" (Tan, \& Tan, 2000, p. 243).

Prior research has established a theoretical link between the two dimensions of organizational trust with various work-related attitudes and behaviours, including organizational commitment (Cook, \& Wall, 1980; Hsu et al., 2013; Zeinabadi, \& Salehi, 2011), employees' productivity (Bahrami et al., 2012), turnover intentions (Aryee et al., 2002; Brashear et al., 2005; Costigan et al., 2011), deviant workplace behaviour (Demir, 2011; Erkutlu, \& Chafra, 2013; Thau et al., 2007), organizational citizenship behaviour, among others (Deluga, 1995; Singh, \& Srivastava, 2009; Yilmaz, \& Tasdan, 2009).

In general, the aforementioned empirical studies suggest that organisational trust may play a significant role in enhancing employees' productivity, stimulates voluntary behaviour that goes beyond what is required in the job, reduces the propensity of employee to quit his or her job and then minimizes the individual propensity to engage in voluntary behaviour that threaten the well being of organisational stakeholders. Despite the aforementioned empirical research, little work has been carried out to examine how organisational trust may facilitate the tendency of an employee to quit his or her job, particularly in the Nigerian context, which differs much in culture with that of western context, such as United States and Europe. Hence, there is a need to understand the effects of organisational trust on turnover intentions in developing nations, particularly in Nigeria.

\subsection{Perceived HRM Practices}

Human resource management Practices refer to "all practices (e.g. annual performance appraisals), specific policies (e.g. equal opportunities), tools (e.g. employee surveys) or techniques (e.g. management by objectives) that contribute to managing human resources in an organisation" (Petersitzke, 2009, p. 1). Literature suggests that HR Practices is a multi-dimensional construct consisting of at least two dimensions, including training and development, recruitment and selection, compensation practices, employee feedback, information exchange, employment security, workforce structure, and performance management, among others (Ahmad, \& Schroeder, 2003; Demo et al., 2012; Fey, \& Björkman, 2001; Huselid, 1995; Ngo et al., 1998; Pfeffer, 1998; Thang, \& Quang, 2005). For the sake of parsimony, the present study focuses mainly on training and development and compensation practices as determinants of turnover intentions in the context of Nigerian higher education institutions. Training and development refers to "a planned effort by a company to facilitate employees' learning of job related competencies. These competencies include knowledge, skills, or behaviors that are critical for successful job performance" (Noe, 2010, p. 5). Compensation practices relate to the entire package of rewards, including financial and non-financial benefits, which an organization provides to its employees in exchange for their services rendered (Aswathappa, 2008; Thomas, 1999).

Substantial amount of past studies have shown that HR practices are related to a variety of workrelated attitudes and behaviours, including organizational commitment (Agarwala, 2003; Fiorito et al., 2007; Kooij, Jansen et al., 2010; Şendoğdu et al., 2013), job satisfaction (Chow et al., 2007; Petrescu, \& Simmons, 2008; Saridakis et al., 2013), organizational citizenship behaviour (Kehoe, \& Wright, 2013; Morrison, 1996; Sun, Aryee, \& Law, 2007; Wei et al., 2010), and deviant workplace behaviour (Arthur, 2011; Kura et al. 2013; Shamsudin et al., 2012). In particular, Agarwala's study (2003) showed that perception of innovative HR practices was found to be a significant determinant of employee's organizational commitment. In a meta-analysis conducted by Kooij, et al. (2010) both affective commitment and job satisfaction were significantly and positively influenced by HR practices. Petrescu and Simmons (2008) reported a significant and positive relationship between HR practices and overall job satisfaction among 1,518 British employees. In a sample of 516 hotel employees in China (Supervisor $=86$; Subordinate $=430$ ), Sun et al. (2007) found significant and 
positive relationship between HR practices and organizational citizenship behaviour (OCB). Recently, Kehoe and Wright (2013) found significant and positive relationship between HR practices and OCB among food service employees. Regarding the influence of HR practices on deviant workplace behaviour (DWB), Arthur's (2011) study showed that perceived HR practices minimize individual's propensity to engage in deviant behaviour towards individuals.

Taken together, extant empirical research in the field of Industrial and Organizational Psychology (I/O) has shown that HR practices, which is characterized by promotion, compensation, and evaluation practices for example are significant predictors of a variety work-related attitudes and behaviours. While substantial amount of past studies have shown that HR practices are related to a variety of work-related attitudes and behaviours, however, literature indicates that prior studies on human resource practices were mainly carried out western context; with relatively few other studies in developing countries. Furthermore, Joarder et al., (2011) noted that, "there is lack of knowledge of how these human resource practices affect individual employees' perceptions, their attitudes, and their behaviors; and what employees actually think and how they react to the practices" (p. 138). Hence, this gap in the literature suggests more should be conducted to understand how HR practices affect a variety work-related attitudes and behaviours in the developing context, particularly, Nigeria. On the basis of theoretical perspectives and empirical studies, a research framework for this study as depicted in Fig. 1 shows the relationship between the independent variables (perceived organizational politics, organizational trust and human resource practices) and the dependent variable (turnover intention).

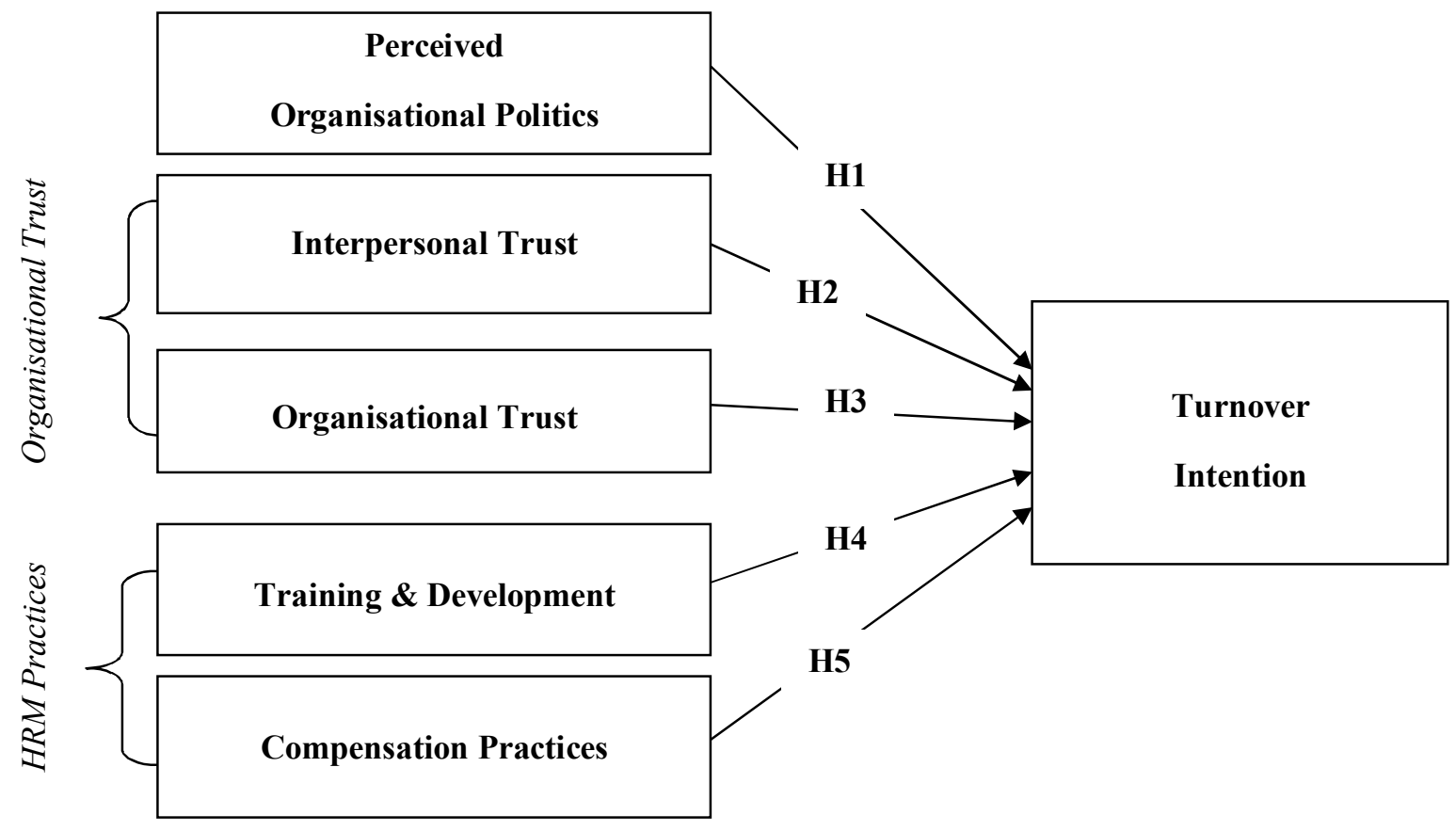

Fig. 1. Research Framework

\section{Method}

\subsection{Sample and procedures}

Data for the present study was collected 175 Registered Nurses participated in the study. Of 175 participants, 128 , representing $73.14 \%$ were female, while the remaining 47 target participants (i.e., $26.86 \%$ ) were their male counterparts. Twenty of the target participants were between 21-30 years old (11.43\%), 62 of them were between 31-40 years old (35.43\%). Majority of the respondents were 
between 41-50 years old (42.86\%), and the remaining 18 of the target participants' age were 51 years and above (10.29\%).Four of the target participants, representing 2.29\% identified as Assistant Director of Nursing Service, $8 \%$ identified as Chief Nursing Officers, $11.43 \%$ were classified as Assistant Chief Nursing Officers, 22.29\% identified as Principal Nursing Officers, 35.43\% identified themselves as Senior Nursing Officers, 12\% identified as Nursing Officers I, and the remaining $8.57 \%$ identified as Nursing Officers II. The target participants have been working for less than 1 year current supervisors for less than 1 year. Forty-eight of the target participants have job experience between $1-5$ years $(27.43 \%), 46(26.29 \%)$ have been working in their profession between $6-10$ years, and 63 of them (36\%) have been working for 11 years and above. Majority of the target participants, representing 70.86\% hold Diploma in Nursing, 22 (i.e., 12.57\%) were holders of Masters Degree and 29 of them, representing $16.57 \%$ hold First Degree.

\subsection{Measures}

\subsubsection{Turnover Intentions}

Three items were adapted to measure turnover intentions from prior research (e.g., Aryee et al., 2001; Lam et al., 2009). Items in this scale are: (1) "There any likelihood that you would resign from the hospital?", (2) "There is likelihood that you would not continue to be a staff of the hospital during your tenure of employment with your present hospital?", and (3) "You have any intentions of resigning from the hospital?". Participants were asked to respond to questions in the turnover intentions scale using a 5-point Likert scale ranged from 1 (strongly disagree) to 5 (strongly agreed). Furthermore, turnover intentions scale demonstrated internal consistency reliability of .86.

\subsubsection{Perceived Organisational Politics}

To assess perceived organisational politics construct, 7-items were adapted from perceptions of organizational politics scale developed by Kacmar and Ferris (1991). Furthermore, following the initial development and validation of this scale, a multiple sample investigation was conducted by Kacmar and Carlson (1997) to further validate the scale. Sample items in this scale are: (1) "Employees in my hospital attempt to build themselves up by tearing others down", (2) "Agreeing with powerful others is the best alternative in my hospital", and (3) "When it comes to pay raise and promotion decisions, policies are irrelevant in my hospital". Participants were asked to respond to questions in this scale using a 5-point Likert scale ranged from 1 (strongly disagree) to 5 (strongly agreed). Perceptions of organizational politics scale demonstrated internal consistency reliability of .87 .

\subsubsection{Organisational Trust}

In order to measure employee's perception regarding organisational trust construct, 12-items were adapted from measures of workplace trust developed by Cook and Wall (1980). Specifically, two underlying dimensions of organisational trust, namely: "interpersonal trust at work", and "trust in organisation" were assessed using Cook and Wall's (1980) measures of trust in the workplace. Interpersonal trust at work subscale comprises of six items. While organisational trust at work subscale was measured by six items. Sample items in this subscale is "Most of my fellow workers would get on with their work even if supervisors were not around". Sample items in this subscale are: (1) "Management of my hospital can be trusted to make sensible decisions for the hospital's future",

(2) "My hospital has a poor future unless it can attract better administrators". Participants were asked to respond to all question in this scale using a 5-point Likert scale ranged from 1 (strongly disagree) to 5 (strongly agreed). 


\subsubsection{HRM Practices}

In the present study, the two underlying dimensions of HRM practices were assessed using 12-item HRM Practices Scale developed by Lam et al., (2009). Specifically, six items were adapted to measure employee's perception regarding the training and development and the remaining six items were used to assess employee's perception of compensation practices. Sample items in this scale are: (1) "The amount and duration of training programmes offered in my hospital are satisfactory". (2) "In my hospital, extensive training programmes have already been systematized". The participants were also responded to question in this scale using a 5-point Likert scale ranged from 1 (strongly disagree) to 5 (strongly agreed). The training and development and compensation practices subscales demonstrated internal consistency reliabilities of .98. and .93. respectively.

\section{Results}

Prior to the regression analysis, several assumptions were met, including the assumption of outliers, linearity, normality assumption, and multicollinearity assumption (Hair et al., 2010; Tabachnick, \& Fidell, 2007). In particular, all data were screened for missing values using SPSS. No missing data was found. Next, multivariate outliers were checked and five items were detected as having outliers. It worth noting that removing those five outliers may not affect the results of this study, hence none of the five outliers detected were deleted, thereby leaving our final data set to 175. All items in the dataset were screened to ensure that normality assumption was not violated.

\subsection{Descriptive Statistics of the Study Variables}

Means and standard deviations were calculated for each of the 6 variables as shown in Table 1. For the 5-point scales (perceived organisational politics, interpersonal trust, organisational trust, training and development, compensation practices and turnover intentions), means ranged from 2.41 to 4.04 , and standard deviations ranged from .64 to .83 .

\section{Table 1}

Descriptive Statistics of the Study Variables

\begin{tabular}{lcc}
\hline Variable & Mean & Std. Deviation \\
\hline Turnover Intentions & 4.04 & .83 \\
Perceived Politics & 3.71 & .67 \\
Interpersonal Trust & 2.41 & .64 \\
Organisational Trust & 3.03 & .77 \\
Training and Development & 2.15 & .73 \\
Compensation Practices & 3.07 & .81 \\
\hline
\end{tabular}

\subsection{Hypothesis Testing}

In the present study, Pearson correlation and simple regression were both utilized to test the relationship between perceived organisational politics, organisational trust, human resource management practices and turnover intention. The correlations among the study's variables are presented in Table 2. As indicated in Table 2, perception of organizational politics was significantly and positively associations with turnover intentions $(\mathrm{r}=.44, \mathrm{p}<.01)$, thus, supporting hypothesis 1 . Perception of interpersonal trust was also significantly and negatively associated with turnover intentions $(r=-.39, p<.01)$. Hence, hypothesis 2 was confirmed. However, contrary to expectations, perception of organisational trust was not found to be significantly associated with turnover intentions $(\mathrm{r}=-.01$, n.s.). As such, hypothesis 3 was not confirmed. Furthermore, training and development was found to be significantly and negatively related with turnover intentions $(\mathrm{r}=-.58, \mathrm{p}<.01)$. Therefore, hypothesis 4 was confirmed. The results also demonstrate a significant and negative association 
between compensation practices and turnover intentions $(\mathrm{r}=-.16, \mathrm{p}<.05)$. Thus, hypothesis 5 was supported.

Table 2

Correlations for Study Variables

\begin{tabular}{|c|c|c|c|c|c|c|c|}
\hline & Variables & 1 & 2 & 3 & 4 & 5 & 6 \\
\hline 1 & Turnover Intentions & 1 & & & & & \\
\hline 2 & Perception of Politics & $.44 * *$ & 1 & & & & \\
\hline 3 & Interpersonal Trust & $-.39 * *$ & $-.62 * *$ & 1 & & & \\
\hline 4 & Organisational Trust & -.01 & .21 & -.12 & 1 & & \\
\hline 5 & Training and Development & $-.55 * *$ & $-.58 * *$ & $.45^{* *}$ & -.21 & 1 & \\
\hline 6 & Compensation Practices & $-.16^{*}$ & -.01 & -.06 & $.23 * *$ & .05 & 1 \\
\hline
\end{tabular}

Because correlational analyses provide only limited information regarding the cause and effect, it is pertinent to further confirmed or disconfirmed the research hypotheses from the results of regression analyses. Furthermore, to ascertain the contribution of the predictor variables in explaining the turnover intentions, regression analyses was performed. The results of regression analyses are presented in Table 3. As indicated in Table 3 that the five predictor variables (i.e., perception of organisational politics, interpersonal trust, organisational trust, training and development, and compensation practices) collectively contributed to $37 \%$ of the variance in turnover intentions with $\mathrm{R}^{2}$ value of 0.37 .

Table 3

Results of a Multiple Regression Analysis (Turnover Intentions as Dependent Variable)

\begin{tabular}{clccccl}
\hline Hypotheses & Relations & Beta & SE & t-value & p-value & Findings \\
\hline H1 & Perceived politics & .17 & .11 & $1.55^{*}$ & .06 & Supported \\
H2 & Interpersonal trust & -.18 & .10 & $-1.73^{* *}$ & .04 & Supported \\
H3 & Organisational trust & -.13 & .07 & $-1.84^{* *}$ & .03 & Supported \\
H4 & Training and development & -.50 & .09 & $-5.66^{* * *}$ & .00 & Supported \\
H5 & Compensation practices & -.12 & .06 & $-1.87^{* *}$ & .03 & Supported \\
\hline
\end{tabular}

Note: ${ }^{*} \mathrm{p}<0.10, * * \mathrm{p}<0.05, * * \mathrm{p}<0.01$

Specifically, Hypothesis 1 suggests that perceived organisational politics is positively related to turnover intentions. As shown in Table 3, a positive and significant relationship was found between perception of organisational politics and turnover intentions $(\beta=.17 ; \mathrm{t}=1.55 ; \mathrm{p}<0.10)$. Hence, indicating support for this hypothesis 1. Hypothesis 2 proposed that interpersonal trust is negatively related to turnover intentions. As shown in Table 3, results indicated a negative and significant relationship between interpersonal trust and turnover intentions intentions $(\beta=-.18 ; \mathrm{t}=-1.73 ; \mathrm{p}<$ 0.05). Thus, Hypothesis 2 was supported, such that interpersonal trust reduces the tendency of employees to quit their job. Hypothesis 3 proposed that organisational trust is negatively related to turnover intentions. This hypothesis was also tested using multiple regressions (see Table 3). As expected, results indicated a negative and significant relationship between organisational trust and turnover intentions intentions $(\beta=-.13 ; \mathrm{t}=-1.84 ; \mathrm{p}<0.05)$. The results provide support for hypothesis 3 , indicating higher level of participants' perceptions of trust with the organization lead to decrease in turnover intentions. Hypothesis $\mathbf{4}$ stated that training and development is negatively related to turnover intentions. An examination of results in Table 3 indicated that training and development is negatively and significantly related with turnover intentions intentions $(\beta=-.50 ; \mathrm{t}=$ 5.66; $\mathrm{p}<0.01$ ). Thus, hypothesis 4 was supported, such that the higher participants' perceptions of training and development, the lower their level of turnover intentions. Hypothesis 5 stated that perception of compensation practices is negatively related to turnover intentions. As shown in Table 3 , a negative and significant relationship was found between perception of compensation practices and turnover intentions $(\beta=-.12 ; \mathrm{t}=-1.87 ; \mathrm{p}<0.05)$. Hence, indicating support for this hypothesis 5 , such that the higher participants' perception of compensation practices, the lower their level of turnover intentions. 


\subsection{Discussion}

This study investigated the relationships between perceived organizational politics, organizational trust, human resource practices and turnover intention among Registered Nurses in Nigerian public hospitals. Using affective events theory (AET; Weiss, \& Cropanzano, 1996) and Blau's (1964) social exchange theory as an underpinning theories, it follows that employees who perceive higher level of organizational politics are likely to quit their jobs. Similarly, perceptions of higher level of organizational trust and human resource practices reduce the tendency of employees to quit their job. The present study revealed several relationships between the independent variables and the dependent variable (i.e., turnover intentions). The next section, discusses on the findings on the relationships between the independent variables and the dependent variable.

The first hypothesis predicted that perceived organisational politics is positively related to turnover intentions. This hypothesis was fully supported with perception of organisational politics significantly and positively related to turnover intentions. This finding extends previous studies that found significant and positive relationships between perceived organisational politics and turnover intentions (Abbas et al., 2012; Bedi, \& Schat, 2013; Harris et al., 2007; Huang et al., 2003; Miller et al., 2008; Vigoda, 2000). Consistent with previous research that found organisational trust predicted turnover intentions (Aryee et al., 2002; Brashear et al., 2005; Costigan et al., 2011; Hemdi, \& Nasurdin, 2006), the results of the present study provide strong support for the second and third hypotheses. As expected, the two dimensions of organisational trust were negatively related to turnover intentions. Employees who perceived higher level of organisational trust were least likely to quit their jobs.

The fourth hypothesis was also supported. As anticipated, training and development was found to be negatively related to turnover intentions. Similar to previous studies (Ashar et al., 2013; Dysvik, \& Kuvaas, 2008; Rahman, \& Nas, 2013), the higher participants' perceptions of training and development, the lower their level of turnover intentions. Similar to previous studies (e.g., Joarder, 2012; Joarder et al., 2011), employees who perceive compensation practices to be reasonably fair are less likely to quit their job. As expected in the present study, perception of compensation practices is significantly and negatively related turnover intentions, indicating support for the fifth hypothesis.

\subsection{Implications of the Study}

Generally, the findings of the present study have theoretical and practical implications. Theoretically, prior research has shown that organizational-related factors including perceived organizational justice (Ali, \& Jan, 2012; Cantor et al., 2011; Koys, 2001; Parker, \& Kohlmeyer III, 2005), organizational culture (Deery, \& Shaw, 1999; Gregory et al., 2009; San-Park, \& Kim, 2009; Way et al., 2007), job satisfaction (Grissom et al., 2012; Hellman, 1997; Koys, 2001; Mobley, 1977; San-Park, \& Kim, 2009; Yau-De et al., 2012), human resource management practices (Allen et al., 2003; Batt, \& Valcour, 2003; Haines III et al., 2009; Kim, 2012; Long et al., 2012; Staufenbiel, \& König, 2010), perceived psychological contract breach (Blomme et al., 2010; Kickul, \& Lester, 2001) and perceived organizational support, among others (DeConinck, \& Johnson, 2009; Jawahar, \& Hemmasi, 2006; Maertz et al., 2007) are likely to have a significant influence on employee turnover.

The present study builds upon the aforementioned studies by examining the relationship between perceived organizational politics, organizational trust, human resource practices and turnover intentions among Nigerian health workers. Specifically, this study contributes to the growing body of research on turnover intentions in several ways. Firstly, by examining the relationship between perceived organizational politics and turnover intentions among Nigerian nurses, this study provides empirical evidence of the role of organisational politics in predicting employees' turnover intentions. The results are in line with the assertion that organisational-related factors play significant role in 
explaining the attitude and behaviour of employees at work because they determine the way and manner employees think, feel, and/or behave (Robbins, \& Judge, 2010). As expected, the findings suggest that perceived organizational politics are effective in minimizing the tendency of employee to quit their jobs. Secondly, in line with Blau's (1964) social exchange theory, present research examined the relative influence of the two underlying dimensions of organisational trust (i.e., interpersonal and organisational trust) on turnover intentions. Therefore, the present study was able to further confirm and validate Blau's (1964) social exchange theory in Nigerian context, particularly the health sector. Thirdly, the findings of this study also underscore the importance of HRM practices in explaining turnover intentions. Hence, the findings suggest that training and development as well compensation practices are theoretically an important factors predicting turnover intentions.

From practical perspective, understanding the underlying factors influencing nurses' turnover intentions to leave has important practical implications for management and hospital administrators. As demonstrated by previous research, high level of organizational politics is associated with high turnover intentions (Abbas et al., 2012; Bedi, \& Schat, 2013; Chinomona, \& Chinomona, 2013), whereas and high level of organizational trust is associated decrease in turnover intentions (Costigan et al., 2011). Similarly, when employees perceive that they are being provided with fair compensation as well as training and development by their employer, they are less likely to leave the organisation (Ashar et al., 2013; Dhiman, \& Mohanty, 2010). The present study suggest that one way to reduce turnover intentions is to ensure that among Registered Nurses are provided with fair compensation as well as training and development by their employer. The present study also stresses the importance of principle of fair play in organizational politics for for management and hospital administrators. The results show that both perceived organizational politics and organizational trust are important consideration in managing turnover intentions among Nigerian nurses.

\subsection{Limitations and Future Research Directions}

While the present study has provided support for all hypothesized relationships, however, several of its limitations need to be recognized and discussed. First of all, although, this study adopted a crosssectional design, it is not possible to draw conclusion from the population as the data for this research was collected at one point in time. Therefore, in view of this methodological limitation, future research could extend this study by adopting a longitudinal design, so that data will be collected at different points in time to enable researchers draw conclusion from the population. Another methodological limitation of the present study relates to R-squared value that has been reported. The present study reported $37 \%$ of the total variance in turnover intentions, which suggests that there are other factors that could significantly explain the variance in employees' intention to turnover. Additionally, the present study suggests that the remaining $63 \%$ of the total variance explains are beyond the scope of this study. Therefore, future research could be conducted by considering other underlying factors that explain turnover intentions among Registered Nurses in Nigeria public hospitals. Specifically, future research could extend the present study by examining other dimensions of HRM practices, such as career management, performance appraisal, and recruitment system that may play significant role in explaining turnover intentions. Finally, it was noted that the target participants were mainly on Registered Nurses from public hospitals located in Kaduna, Nigeria. As such it is not possible to generalize the findings of the present study. The present study recommended that future research need to be conducted by collecting data from diverse populations, including Registered Nurses from private hospitals to allow comparisons to be made with prior research as well as to generalize the findings.

\section{Conclusion}

The present study investigated the relationship between perceived organizational politics, organizational trust, human resource practices and turnover intentions among Registered Nurses in 
Nigerian public hospitals. Results supported all the hypothesized relationships between perception of organizational politics, organizational trust, human resource practices and turnover intentions. Results also have important implications for management and hospital administrators. Employee perceptions of organizational politics are associated with their turnover intentions. When management and hospital administrators realize that perceptions of organizational politics significantly predict turnover intentions, they may introduce the principle of fair and play organizational politics which is more likely to reduce intention to turnover among nurses. This in turn would help the entire public hospital succeed because performance levels of these nurses would increase. The present study supported prediction that human resource practices related negatively with turnover intentions. These findings can help guide human resource practices including the designing of training for developing effective human capital as well as designing fair compensation practices that would go along in motivating Registered Nurses in their respective hospitals.

\section{References}

Abbas, M., Raja, U., Darr, W., \& Bouckenooghe, D. (2012). Combined effects of perceived politics and psychological capital on job satisfaction, Turnover intentions, and performance. Journal of Management. doi: 10.1177/0149206312455243

Adebayo, S. O., \& Ogunsina, S. O. (2011). Influence of supervisory behaviour and job stress on job satisfaction and turnover intention of police personnel in Ekiti state. [Article]. Journal of Management \& Strategy, 2(3), 13-20. doi: 10.5430/jms.v2n3p13

Agarwala, T. (2003). Innovative human resource practices and organizational commitment: An empirical investigation. The International Journal of Human Resource Management, 14, 175-197. doi: 10.1080/0958519021000029072

Agency Reporter. (2012, June 5). African varsities must be urgently mended, brain drain stemmed, The Punch. Retrieved from http://www.punchng.com/education/african-varsities-must-beurgently-mended-brain-drain-stemmed/

Ahmad, S., \& Schroeder, R. G. (2003). The impact of human resource management practices on operational performance: recognizing country and industry differences. Journal of Operations Management, 21(1), 19-43. doi: http://dx.doi.org/10.1016/S0272-6963(02)00056-6

Ajzen, A., \& Fishbein, M. (1980). Understanding attitudes and predicting social behavior. Englewood Cliffs, NJ: Prentice-Hall.

Ali, N., \& Jan, S. (2012). Relationship between Organizational Justice and Organizational Commitment and Turnover Intentions amongst Medical Representatives of Pharmaceuticals Companies of Pakistan. [Article]. Journal of Managerial Sciences, 6(2), 201-212.

Allen, D. G., Shore, L. M., \& Griffeth, R. W. (2003). The role of perceived organizational support and supportive human resource practices in the turnover process. Journal of Management, 29(1), 99-118. doi: 10.1177/014920630302900107

Arthur, J. B. (2011). Do HR system characteristics affect the frequency of interpersonal deviance in organizations? The role of team autonomy and internal labor market practices. Industrial Relations: A Journal of Economy and Society, 50(1), 30-56. doi: 10.1111/j.1468232X.2010.00624.X

Aryee, S., Budhwar, P. S., \& Chen, Z. X. (2002). Trust as a mediator of the relationship between organizational justice and work outcomes: Test of a social exchange model. Journal of Organizational Behaviour, 23(3), 267-285. doi: 10.1002/job.138

Aryee, S., \& Yue Wah, C. (2001). Workplace justice, citizenship behaviour, and turnover intentions in a union context: Examining the mediating role of perceived union support and union instrumentality. Journal of Applied Psychology, 86, 154-160. doi: 10.1037//0021-9010.86.1.154

Ashar, M., Ghafoor, M. M., Munir, E., \& Hafeez, S. (2013). The impact of perceptions of training on employee commitment and turnover intention: Evidence from Pakistan. International Journal of Human Resource Studies, 3(1), 74-88. 
Aswathappa, K. (2008). Human resource management: Text and cases. Delhi Tata McGraw-Hill Publishing Company Limited.

Bahrami, S., Hasanpour, M., Rajaeepour, S., Aghahosseni, T., \& Hodhodineghad, N. (2012). The relationship between organizational trust and nurse administrators' productivity in hospitals. Iranian Journal of Nursing and Midwifery Research, 17, 451-455.

Bassi, S. Y. (2004, September 20 -22). The Role of the Directorate of Technical Cooperation in Africa (DTCA) in technology transfer and acquisition in African countries. Paper presented at the 2nd African Regional Conference on Engineering Education, University of Lagos, Nigeria

Batt, R., \& Valcour, P. M. (2003). Human resources practices as predictors of work-family outcomes and employee turnover. Industrial Relations: A Journal of Economy and Society, 42, 189-220. doi: $10.1111 / 1468-232 \times .00287$

Bedi, A., \& Schat, A. C. H. (2013). Perceptions of organizational politics: A meta-analysis of its attitudinal, health, and behavioural consequences. Canadian Psychology/Psychologie canadienne, 54, 246-259. doi: 10.1037/a0034549

Beecroft, P. C., Dorey, F., \& Wenten, M. (2008). Turnover intention in new graduate nurses: a multivariate analysis. Journal of Advanced Nursing, 62(1), 41-52. doi: 10.1111/j.13652648.2007.04570.x

Blau, P. M. (1964). Exchange and power in social life. New York: Transaction Publishers.

Blomme, R. J., van Rheede, A., \& Tromp, D. M. (2010). The use of the psychological contract to explain turnover intentions in the hospitality industry: a research study on the impact of gender on the turnover intentions of highly educated employees. The International Journal of Human Resource Management, 21, 144-162. doi: 10.1080/09585190903466954

Brashear, T. G., Manolis, C., \& Brooks, C. M. (2005). The effects of control, trust, and justice on salesperson turnover. Journal of Business Research, 58(3), 241-249. doi: 10.1016/s01482963(03)00134-6

Cantor, D. E., Macdonald, J. R., \& Crum, M. R. (2011). The Influence of Workplace Justice Perceptions on Commercial Driver Turnover Intentions. [Article]. Journal of Business Logistics, 32(3), 274-286. doi: 10.1111/j.2158-1592.2011.01022.x

Carnevale, D. G., \& Wechsler, B. (1992). Trust in the public sector: Individual and organizational determinants. Administration \& Society, 23, 471-494. doi: 10.1177/009539979202300404

Cascio, W. F. (2000). Costing human resources: The financial impact of behavior in organizations (4th ed.). Boston, MA: PWS-Kent Publishing Company.

Chinomona, R., \& Chinomona, E. (2013). The influence of employees' perceptions of organizational politics on turnover intentions in Zimbabwe's SME sector. South African Journal of Business Management, 44, 57-66.

Chow, C. W., Haddad, K., \& Singh, G. (2007). Human Resource Management, Job Satisfaction, Morale, Optimism, and Turnover. International Journal of Hospitality \& Tourism Administration, 8(2), 73-88. doi: 10.1300/J149v08n02_04

Cook, J., \& Wall, T. (1980). New work attitude measures of trust, organizational commitment and personal need non-fulfillment. Journal of Occupational Psychology, 53, 39-52.

Costigan, R. D., Insinga, R. C., Berman, J. J., Kranas, G., \& Kureshov, V. A. (2011). Revisiting the relationship of supervisor trust and $\mathrm{CEO}$ trust to turnover intentions: A three-country comparative study. Journal of World Business, 46(1), 74-83. doi: http://dx.doi.org/10.1016/j.jwb.2010.05.019

Cotton, J. L., \& Tuttle, J. M. (1986). Employee turnover: A meta-analysis and review with implications for research. The Academy of Management Review, 11(1), 55-70. doi: $10.2307 / 258331$

DeConinck, J. B., \& Johnson, J. T. (2009). The effects of perceived supervisor support, perceived organizational support, and organizational justice on turnover among salespeople. Journal of Personal Selling and Sales Management, 29, 333-351. doi: 10.2753/PSS0885-3134290403

Deery, M. A., \& Shaw, R. N. (1999). An investigation of the relationship between employee turnover and organizational culture. Journal of Hospitality \& Tourism Research, 23, 387-400. doi: $10.1177 / 109634809902300404$ 
Deluga, R. J. (1995). The relation between trust in the supervisor and subordinate organizational citizenship behavior. Military Psychology, 7(1), 1-16. doi: 10.1207/s15327876mp0701_1

Demir, M. (2011). Effects of organizational justice, trust and commitment on employees' deviant behavior. Anatolia, 22, 204-221. doi: 10.1080/13032917.2011.597934

Demo, G., Neiva, E. R., Nunes, I., \& Rozzett, K. (2012). Human resources management policies and practices scale: Exploratory and confirmatory factor analysis. BAR - Brazilian Administration Review, 9(4), 395-420.

Dhiman, G. R., \& Mohanty, R. P. (2010). HRM Practices, Attitudinal Outcomes and Turnover Intent: An Empirical Study in Indian Oil and Gas Exploration and Production Sector. South Asian Journal of Management, 17(4), 74-104.

Dysvik, A., \& Kuvaas, B. (2008). The relationship between perceived training opportunities, work motivation and employee outcomes. International Journal of Training and Development, 12(3), 138-157. doi: 10.1111/j.1468-2419.2008.00301.x

Erkutlu, H., \& Chafra, J. (2013). Effects of trust and psychological contract violation on authentic leadership and organizational deviance. Management Research Review, 36, 828-848. doi: 10.1108/MRR-06-2012-0136

Ferris, G. R., Harrell-Cook, G., \& Dulebohn, J. H. (2000). Organizational politics: The nature of the relationship between politics perceptions and political behaviour. Research in the Sociology of Organizations, 17, 89-130.

Fey, C. F., \& Björkman, I. (2001). The effect of human resource management practices on MNC subsidiary performance in Russia. Journal of International Business Studies, 32(1), 59-75. doi: $10.2307 / 3069510$

Fiorito, J., Bozeman, D. P., Young, A., \& Meurs, J. A. (2007). Organizational commitment, human resource practices, and organizational characteristics. Journal of Managerial Issues, 19, 186-207.

Fishbein, M., \& Ajzen, I. (1975). Belief, attitude, intention and behavior: An introduction to theory and research. Reading, MA: Addison-Wesley.

Glebbeek, A. C., \& Bax, E. H. (2004). Is high employee turnover really harmful? an empirical test using company records. Academy of Management Journal, 47, 277-286. doi: 10.2307/20159578

Gouldner, A. W. (1960). The norm of reciprocity: A preliminary statement. American Sociological Review, 161-178.

Gregory, B. T., Harris, S. G., Armenakis, A. A., \& Shook, C. L. (2009). Organizational culture and effectiveness: A study of values, attitudes, and organizational outcomes. Journal of Business Research, 62, 673-679. doi: http://dx.doi.org/10.1016/j.jbusres.2008.05.021

Grissom, J. A., Nicholson-Crotty, J., \& Keiser, L. (2012). Does My Boss's Gender Matter? Explaining Job Satisfaction and Employee Turnover in the Public Sector. Journal of Public Administration Research \& Theory, 22, 649-673.

Haines III, V. Y., Jalette, P., \& Larose, K. (2009). Influence of human resource management practices on employee voluntary turnover rates in the Canadian non governmental sector. Indus. \& Lab. Rel. Rev., 63, 228.

Hair, J. F., Black, W. C., Babin, B. J., \& Anderson, R. E. (2010). Multivariate data analysis (7th ed.). Upper Saddle River, New Jersey: Prentice Hall.

Harris, K., Andrews, M., \& Kacmar, K. (2007). The moderating effects of justice on the relationship between organizational politics and workplace attitudes. Journal of Business \& Psychology, 22, 135-144. doi: 10.1007/s10869-007-9054-9

Hellman, C. M. (1997). Job Satisfaction and Intent to Leave. Journal of Social Psychology, 137, 677689.

Hemdi, M. A., \& Nasurdin, A. M. (2006). Predicting turnover intentions of hotel employees: The influence of employee development human resource management practices and trust in organization. Gadjah Mada International Journal of Business, 8(1), 21-42.

Holtom, B. C., Mitchell, T. R., Lee, T. W., \& Eberly, M. B. (2008). Turnover and retention research: A glance at the past, a closer review of the present, and a venture into the future. Academy of Management Annals, 2, 231-274. doi: 10.1080/19416520802211552 
Hsu, C.-P., Chiang, C.-Y., Chang, C.-W., Huang, H.-C., \& Chen, C.-C. (2013). Enhancing the commitment of nurses to the organisation by means of trust and monetary reward. Journal of Nursing Management, n/a-n/a. doi: 10.1111/jonm.12180

Huang, I.-C., Chuang, C.-H. J., \& Lin, H.-C. (2003). The role of burnout in the relationship between perceptions of organizational politics and turnover intentions. Public Personnel Management, 32, 519-531. doi: 10.1177/009102600303200404

Huselid, M. A. (1995). The impact of human resource management practices on turnover, productivity, and corporate financial performance. The Academy of Management Journal, 38, 635672. doi: $10.2307 / 256741$

Jawahar, I., \& Hemmasi, P. (2006). Perceived organizational support for women's advancement and turnover intentions: The mediating role of job and employer satisfaction. Women in Management Review, 21, 643-661. doi: 10.1108/09649420610712036

Joarder, M. H. (2012). The role of HRM practices in predicting faculty turnover intention: empirical evidence from private universities in Bangladesh. The South East Asian Journal of Management, $5,159-178$.

Joarder, M. H. R., Sharif, M. Y., \& Ahmmed, K. (2011). Mediating role of affective commitment in HRM practices and turnover intention relationship: A study in a developing context. Business \& Economics Research Journal, 2, 135-158.

Kacmar, K. M., \& Carlson, D. S. (1997). Further validation of the perceptions of politics scale (pops): A multiple sample investigation. Journal of Management, 23, 627-658. doi: http://dx.doi.org/10.1016/S0149-2063(97)90019-2

Kacmar, K. M., \& Ferris, G. R. (1991). Perceptions of Organizational Politics Scale (POPS): Development and construct validation. Educational and Psychological Measurement, 51, 193-205. doi: $10.1177 / 0013164491511019$

Kehoe, R. R., \& Wright, P. M. (2013). The impact of high-performance human resource practices on employees' attitudes and behaviours. Journal of Management, 39, 366-391. doi: $10.1177 / 0149206310365901$

Kickul, J., \& Lester, S. (2001). Broken promises: Equity sensitivity as a moderator between psychological contract breach and employee attitudes and behavior. Journal of Business and Psychology, 16, 191-217. doi: 10.1023/a:1011105132252

Kim, S. (2012). The impact of human resource management on state government IT employee turnover intentions. Public Personnel Management, 41, 257-279.

Kooij, D. T. A. M., Jansen, P. G. W., Dikkers, J. S. E., \& De Lange, A. H. (2010). The influence of age on the associations between HR practices and both affective commitment and job satisfaction: A meta-analysis. Journal of Organizational Behaviour, 31, 1111-1136. doi: 10.1002/job.666

Koys, D. J. (2001). The effects of employee satisfaction, organizational citizenship behavior, and turnover on organizational effectiveness: A unit-level, longitudinal study. Personnel Psychology, 54(1), 101-114. doi: 10.1111/j.1744-6570.2001.tb00087.x

Kura, K. M., Shamsudin, F. M., \& Chauhan, A. (2013). Modeling the influence of group norms and self-regulatory efficacy on workplace deviant behaviour. Asian Social Science, 9(4), 113-122. doi: 10.5539/ass.v9n4p113

Lam, W., Chen, Z., \& Takeuchi, N. (2009). Perceived human resource management practices and intention to leave of employees: the mediating role of organizational citizenship behaviour in a Sino-Japanese joint venture. [Article]. International Journal of Human Resource Management, 20, 2250-2270. doi: 10.1080/09585190903239641

Lee, D.-C., Hung, L.-M., \& Chen, M.-L. (2012). Empirical study on the influence among corporate sponsorship, organizational commitment, organizational cohesiveness and turnover intention. Journal of Management and Sustainability, 2(2), p43.

Long, C. S., Perumal, P., \& Ajagbe, M. A. (2012). Theimpact of human resource management practices on employees' turnover intention: A conceptual model. Interdisciplinary Journal of Contemporary Research in Business, 4, 629-641. 
Maertz, C. P., Griffeth, R. W., Campbell, N. S., \& Allen, D. G. (2007). The effects of perceived organizational support and perceived supervisor support on employee turnover. Journal of Organizational Behavior, 28, 1059-1075. doi: 10.1002/job.472

March, J. G., \& Simon, H. A. (1958). Organization. New York: Wiley.

Mayer, R. C., Davis, J. H., \& Schoorman, F. D. (1995). An integrative model of organizational trust. The Academy of Management Review, 20, 709-734. doi: 10.2307/258792

McKinney, W. R., Bartlett, K. R., \& Mulvaney, M. A. (2007). Measuring the costs of employee turnover in Illinois public park and recreation agencies: An exploratory study. Journal of Park and Recreation Administration, 25(1), 50-74.

Miller, B., Rutherford, M., \& Kolodinsky, R. (2008). Perceptions of organizational politics: A metaanalysis of outcomes. Journal of Business \& Psychology, 22, 209-222. doi: 10.1007/s10869-0089061-5

Mobley, W. H. (1977). Intermediate linkages in the relationship between job satisfaction and employee turnover. Journal of Applied Psychology, 62(2), 237-240. doi: 10.1037/00219010.62.2.237

Mobley, W. H. (1982). Employee turnover: Causes, consequences, and control. Reading, MA: Addison-Wesley.

Mobley, W. H., Griffeth, R. W., Hand, H. H., \& Meglino, B. M. (1979). Review and conceptual analysis of the employee turnover process. Psychological Bulletin, 86(3), 493-522. doi: 10.1037/0033-2909.86.3.493

Moore, J. E. (2000). One road to turnover: An examination of work exhaustion in technology professionals. Management Information Systems Quarterly, 24(1), 141-168.

Morrison, E. W. (1996). Organizational citizenship behavior as a critical link between HRM practices and service quality. Human Resource Management, 35, 493-512. doi: 10.1002/(sici)1099050x(199624)35:4<493::aid-hrm4>3.0.co;2-r

Munzali, J., \& Obaje, A. (2008). Nigeria." In Higher Education in Africa: the International Dimension. In D. Teferra \& J. Knight (Eds.), (pp. 339-366). Boston: Center for International Higher Education and Association of African Universities.

Ngo, H.-Y., Turban, D., Lau, C.-M., \& Lui, S.-Y. (1998). Human resource practices and firm performance of multinational corporations: influences of country origin. [Article]. International Journal of Human Resource Management, 9, 632-652. doi: 10.1080/095851998340937

Noe, R. A. (2010). Employee training and development (5 ed.). New York, NY: McGraw-Hill/Irwin Boston.

Nyhan, R. C., \& Marlowe, H. A. (1997). Development and psychometric properties of the organizational trust inventory. Evaluation Review, 21(5), 614-635. doi: $10.1177 / 0193841 \times 9702100505$

Parker, R. J., \& Kohlmeyer III, J. M. (2005). Organizational justice and turnover in public accounting firms: a research note. Accounting, Organizations and Society, 30, 357-369. doi: $10.1108 / 17511870910928001$

Petersitzke, M. (2009). Managing psychological contracts through human resource practices Supervisor psychological contract management (pp. 119-129). Wiesbaden: Gabler Verlag.

Petrescu, A. I., \& Simmons, R. (2008). Human resource management practices and workers' job satisfaction. International Journal of Manpower, 29, 651-667. doi: 10.1108/01437720810908947

Pfeffer, J. (1998). Seven practices of successful organizations. California Management Review, 40(2), 96-124.

Poon, J. M. L. (2004). Effects of performance appraisal politics on job satisfaction and turnover intention. Personnel Review, 33, 322-334.

Porter, L. W., \& Steers, R. M. (1973). Organizational, work, and personal factors in employee turnover and absenteeism. Psychological Bulletin, 80(2), 151-176. doi: 10.1037/h0034829

Price, J. L. (1977). The study of turnover. Ames, IA: Iowa State University Press.

Rahman, W., \& Nas, Z. (2013). Employee development and turnover intention: theory validation. European Journal of Training and Development, 37(6), 564-579. 
Robbins, S. P., \& Judge, T. A. (2010). Organizational Behaviour (14 ed.). New York: Prentice Hall

San Park, J., \& Kim, T. H. (2009). Do types of organizational culture matter in nurse job satisfaction and turnover intention? Leadership in Health Services, 22(1), 20-38.

Sanderson, A., Phua, V., \& Herda, D. (2000). The American faculty poll. New York: National Opinion Research Center, Illinois, Chicago.

Saridakis, G., Muñoz Torres, R., \& Johnstone, S. (2013). Do human resource practices enhance organizational commitment in SMEs with low employee satisfaction? British Journal of Management, 24, 445-458. doi: 10.1111/j.1467-8551.2012.00814.x

Schyns, B., Torka, N., \& Gössling, T. (2007). Turnover intention and preparedness for change: exploring leader-member exchange and occupational self-efficacy as antecedents of two employability predictors. Career Development International, 12(7), 660-679.

Şendoğdu, A. A., Kocabacak, A., \& Güven, Ş. (2013). The Relationship between Human Resource Management Practices and Organizational Commitment: A Field Study. Procedia - Social and Behavioral Sciences, 99, 818-827. doi: http://dx.doi.org/10.1016/j.sbspro.2013.10.553

Shamsudin, F. M., Subramaniam, C., \& Alshuaibi, A. S. (2012). The effect of HR practices, leadership style on cyberdeviance: The mediating role of organizational commitment. Journal of Marketing and Management, 3(1), 22-48.

Singh, U., \& Srivastava, K. L. (2009). Interpersonal trust and organizational citizenship behavior. Psychological Studies, 54(1), 65-76. doi: 10.1007/s12646-009-0008-3

Staufenbiel, T., \& König, C. J. (2010). A model for the effects of job insecurity on performance, turnover intention, and absenteeism. Journal of Occupational and Organizational Psychology, 83(1), 101-117. doi: 10.1348/096317908x401912

Sun, L.-Y., Aryee, S., \& Law, K. S. (2007). High-performance human resource practices, citizenship behaviour, and organizational performance: A relational perspective. The Academy of Management Journal, 50, 558-577. doi: 10.2307/20159873

Tabachnick, B. G., \& Fidell, L. S. (2007). Using multivariate statistics (5th ed.). Boston: Allyn and Bacon.

Tan, H. H., \& Tan, C. S. F. (2000). Toward the differentiation of trust in supervisor and trust in organization. [Article]. Genetic, Social \& General Psychology Monographs, 126(2), 241-260.

Tett, R. P., \& Meyer, J. P. (1993). Job satisfaction, organizational commitment, turnover intention, and turnover: Path analyses based on meta-analytic findings. Personnel Psychology, 46, 259-293. doi: 10.1111/j.1744-6570.1993.tb00874.x

Thang, L. C., \& Quang, T. (2005). Antecedents and consequences of dimensions of human resource management practices in Vietnam. The International Journal of Human Resource Management, 16, 1830-1846. doi: 10.1080/09585190500298420

Thau, S., Crossley, C., Bennett, R. J., \& Sczesny, S. (2007). The relationship between trust, attachment, and antisocial work behaviours. Human Relations, 60, 1155-1179.

Thomas, S. L. (1999). Compensation. In L. H. Peters, C. R. Greer \& S. A. Youngblood (Eds.), Blackwell encyclopedic dictionary of human resource management (pp. 53). Oxford: Blackwell.

Vigoda, E. (2000). Organizational politics, job attitudes, and work outcomes: Exploration and implications for the public sector. Journal of Vocational Behavior, 57, 326-347. doi: http://dx.doi.org/10.1006/jvbe.1999.1742

Waswa, F., \& Katana, G. (2008). Academic staff perspectives on operating beyond industrial actions for sustainable quality assurance in public universities in Kenya. International Journal of Environment, Workplace and Employment, 4(1), 45-58.

Way, C., Gregory, D., Davis, J., Baker, N., LeFort, S., Barrett, B., \& Parfrey, P. (2007). The Impact of organizational culture on clinical managers' organizational commitment and turnover intentions. Journal of Nursing Administration, 37, 235-242 doi: 10.1097/01.NNA.0000269741.32513.7f

Wei, Y. C., Han, T. S., \& Hsu, I. C. (2010). High-performance HR practices and OCB: a cross-level investigation of a causal path. The International Journal of Human Resource Management, 21, 1631-1648. doi: 10.1080/09585192.2010.500487 
Weiss, H. M., \& Cropanzano, R. (1996). Affective events theory: A theoretical discussion of the structure, causes and consequences of affective experiences at work. In B. M. Staw \& L. L. Cummings (Eds.), Research in organizational behavior: An annual series of analytical essays and critical reviews (pp. 1-74 ). Greenwich, CT: JAI Press.

Yau-De, W., Chyan, Y., \& Kuei-Ying, W. (2012). Comparing public and private employees' job satisfaction and turnover. [Article]. Public Personnel Management, 41, 557-573.

Yilmaz, K., \& Tasdan, M. (2009). Organizational citizenship and organizational justice in Turkish primary schools. Journal of Educational Administration, 47, 108-126.

Zeinabadi, H., \& Salehi, K. (2011). Role of procedural justice, trust, job satisfaction, and organizational commitment in Organizational Citizenship Behavior (OCB) of teachers: Proposing a modified social exchange model. Procedia - Social and Behavioral Sciences, 29, 1472-1481. doi: http://dx.doi.org/10.1016/j.sbspro.2011.11.387 